\title{
Research and Practice of MOOC Teaching in the Outline of Chinese Modern History
}

\author{
Jie Fan
}

\author{
Department of Political Theory Teaching, Nanyang Institute of Technology, Nanyang, China \\ fanjie12@163.com
}

Keywords: The Outline of Chinese Modern History; MOOC; Reform of Teaching Mode

\begin{abstract}
At present, the application research of MOOC in the ideological and theoretical education in the specific disciplines involved in the shallow, perspective mainly stay in the ideological and theoretical courses how to deal with MOOC challenges, and did not provide operational specific links, theory and practice phase Combined with the study is not deep, not systematic. Under the background, by analyzing the teaching practice of MOOC and the teaching reality of the outline of Chinese modern history, this paper studies the influence of MOOC's educational idea on the curriculum, the change of education and teaching mode, the impact of the effectiveness and the impact of the concept of education, and then from the cross, integration and other aspects of the MOOC on the effectiveness of this course teaching and targeted impact, to find the ideological and political theory of teaching reform model of new ways, operational realistic reference.
\end{abstract}

\section{Introduction}

MOOC (Massive Open Online Courses) is an online course open model that emerged in recent years [9]. MOOC courses integrate a variety of social networking tools and various forms of digital resources; form a wide range of learning tools and rich curriculum resources. MOOC courses break through the traditional curriculum time, space constraints, relying on the Internet around the world of learners at home and abroad can learn well-known university courses. MOOC courses break through the limits of traditional courses, to meet the large-scale course learners learn. MOOC course has a high enrollment rate, but also has a high dropout rate, which requires learners with strong self-learning ability to complete the course content on time.

\section{The Necessity of Teaching Reform of Ideological and Political Theory Course Based on MOOC}

In 2004, the Opinions of the CPC Central Committee and the State Council on Further Strengthening and Improving the Ideological and Political Education of College Students pointed out that "take the initiative to occupy the new position of ideological and political education on the Internet"; The "Opinions on Further Strengthening and Improving the Ideological Work of Colleges and Universities in the New Situation" in 2015 further emphasized that "we should actively cultivate and practice the socialist core values" by focusing on strengthening the construction of university networks and other positions. General Secretary Xi Jinping in the national propaganda meeting on the spirit of the speech requirements, ideological and political theory courses to advance with the times, due to the general trend of the development of the Internet, should be large-scale online course trend, follow the needs of the development of the times, The ideological and political theory into a student really love, life-long benefit, life benefit of the course.

Today's society has entered the era of information technology, the current growth environment of college students, access to information has undergone a fundamental change in the Internet and mobile phones and other mobile has become the main way for college students to obtain information, which put forward ideological and political theory teaching breakthrough Scene, into the cyberspace requirements. The use of MOOC new platform to work together to promote the 
traditional advantages of ideological and political work with information technology is highly integrated, is to adapt to the development of the times, to enhance the effectiveness of teaching the inevitable requirement.

MOOC's advantage lies in: First, open, can implement large-scale teaching; Second, flexibility, students can learn through mobile devices anytime, anywhere, you can control their own learning progress; Third, vivid, through the vivid teaching video real-time teaching, It is helpful to improve students' interest in learning and improve learning initiative. Fourth, it is interactive, including interaction with curriculum content, interaction between teachers and students and interaction between students and students, which is helpful to enhance learning effect.

From the times background of MOOC, MOOC and the combination of ideological and theoretical courses is imperative. The traditional teaching of ideological and political theory in colleges and universities is faced with great challenges and opportunities, so that the Internet and information technology to serve the ideological and political theory course is a very urgent task. Therefore, we must strengthen MOOC and education and teaching reform, innovative education and teaching model, and promote the reform of ideological and theoretical courses in colleges and universities.

\section{The Advantages of "Outline of Modern Chinese History" Using MOOC Teaching}

"Outline of Chinese Modern History" (hereinafter referred to as "outline") has its own unique, teaching goal is to understand the history and national conditions, so that students profoundly understand the history and how people choose Marxism, the Chinese Communist Party, socialist road and Reform and opening up, thus establishing four self-confidence.

"Outline" curriculum has its own characteristics of the discipline, the historical part of the students involved in the junior high school have been studied, students will gradually produce conflict, disgust, lost enthusiasm and interest in learning, and the prevalence of historical nihilism The impact of the content of the historical materialism of teachers will be questioned and questioned. Some students still have cognitive errors, that learning the course useless, and its professional background is not meaningful, meaningless, do not understand history, life is also spent. Of course, some teachers' lectures objectively exist "the formula is relatively old", "the process is relatively backward," packaging is not enough fashion "problem, leading to students wear tired of psychological. The contradiction between teaching and learning is still quite in the teaching of ideological and political theory. In a certain sense, MOOC force the "outline" teaching to reform. But in particular, to strengthen the MOOC and "outline" the combination of professional characteristics of the theory and practice of combining the research and analysis for the "outline" teaching provides a new operational thinking, to improve and innovate the whole The teaching of ideological and theoretical courses in colleges and universities has important practical significance.

\section{Construction of Mixed Teaching Mode Based on MOOC Platform in "Outline" Course}

In the "outline" course teaching, MOOC will be applied to the classroom links, making it part of the classroom teaching, so that the two organic combination.

\subsection{Use MOOC Platform, Enrich the "outline" Course Teaching Content}

At present, the "outline" course of colleges and universities is taught in the classroom of teachers, and the combination of multimedia teaching, this way can enable students to share teaching resources, but its scope is limited, and by our study found that the current student learning The interest is not high, learning the outline of modern Chinese history is relatively low enthusiasm. MOOC platform can effectively solve this problem, it can make the global scope of the "outline" teaching resources to share, MOOC platform to greatly expand the use of students' vision, improve the "outline" course teaching content, rich development The "outline" teaching methods, more important is to stimulate the interest of students to learn to mobilize the enthusiasm of students to learn, initiative and creativity. 


\section{Learn from MOOC Teaching Mode, Change the Traditional Teaching Mode}

The current "outline" classroom teaching is more monotonous, and lack of vitality. In many schools there are even teachers who are lecturing at the podium while the students are sleeping below. Such a problem I think the need for timely solution, MOOC platform is a very good way to solve this problem, in the MOOC platform, there is a "flip classroom" teaching mode, this model, students can both in the dormitory, also Can be at home, complete the network operation, in the face of problems, you can ask the teacher online, teachers can solve the problem online, and teachers can also use the relevant software to monitor student learning. At the same time MOOC platform will be free of resources around the world for teachers and students to enjoy, and promote the use of resources to maximize efficiency.

\section{Students Apply the "MOOC" Autonomous Learning Model}

Multimedia is a way we often see in the teaching process, which is also a way for teachers to praise, but in the new historical period, this method has emerged a lot of problems, and the most common is: Students are not interested in learning, learning autonomy is poor. At present, the "Outline" course of colleges and universities is dominated by such a method. For this reason, I think it is necessary to introduce MOOC as a new teaching method. It can solve this problem effectively. It can make the "Outline" use of resources to achieve sharing, MOOC platform greatly expanded the use of the students vision, improve the "Outline" teaching content, rich development of the "Outline" teaching methods, more important is to enable students to achieve self-learning aims.

\section{The Effect of Curriculum Reform}

From the current teaching practice point of view, MOOC to our curriculum reform to bring infinite vitality, but also achieved certain results.

First, the enthusiasm of teachers to learn greatly improved. In order to prepare for the discussion and rollover of classroom teaching, the project team asked teachers to watch all the teaching videos in advance and discuss the exchange in the group lesson.

Second, the enthusiasm of students to learn has improved. Students can actively discuss and actively speak according to the topic of discussion published by the teacher.

Third, the relevance and effectiveness of the classroom has improved. With the help of large data analysis, teachers understand the "knowledge" of the "outline" course and the students' interest in learning, so as to find the rules of teaching and learning process, in the teaching process according to these laws can be improved. Teachers understand the real progress of students and details, targeted teaching design, to enhance the effectiveness of classroom teaching and targeted.

Fourth, balance the ratio between the theoretical teaching and practice teaching. According to the Ministry of Education, "China Outline of Modern History" provides that, combined with our school, the course of 32 hours, 2 credits. And in the case of less time, the task of heavy teaching, the theory of learning, communication and assessment tasks on the line, leaving more time for students to explore the issue, the ideological contend, but also to teachers to guide the practice of teaching And student practice teaching.

\section{Summary}

The introduction of MOOC in the "Outline" curriculum has also brought new implications to the reform of the "Outline" curriculum, but it is not a revolution. It cannot replace traditional classroom teaching and cannot replace our " Can only be said that the existing classroom teaching supplement and extension. In addition, the online MOOC resources are not targeted, the interaction is not enough, counseling Q \& A slow, discuss the topic of scattered, teaching teachers and students lack of interaction and emotional exchange, the curriculum is integrated, the lack of teachers and students classroom communication interaction temperature and Vivid and many other limitations. Of course, MOOC is still in development. 


\section{Acknowledgement}

The author is grateful to the support of 2017 Nanyang Institute of Technology Education and Teaching Reform Research Project.

\section{References}

[1] L.S. Cai. Journal of Tsinghua University(Philosophy and Social Sciences, (2010) No.S1, p.336.

[2] X.M. Wang, B. Hua. Journal of Ideological and Theoretical Education, (2011) No.6, p.362.

[3] J.S. Sha. China Higher Education, (2007) No.6, p.245.

[4] Y.Q. Zhou, S.Y. Wan. China Education Info, (2016) No.2, p.10.

[5] L.Q. Yang. Education Modernization, (2016) No.3, p.234.

[6] M.X. Zeng, G.P. Li. China Educational Technology, (2015) No.11, p.28.

[7] B. He, Y. Cao. China Educational Technology, (2015) No.3, p.22.

[8] Y.J. Guo. Journal of Higher Education Management, (2014) No.5, p.22.

[9] W.M. Zhang. Information Technology (Academic Research), (2008) No.17, p.45.

[10] T.G. Huo. Journal of Heihe University, (2012) No.5, p.85.

[11] Q.Y. Wang. Shanghai Research on Education, (2014) No.8, p.15. 